\title{
CIJEPLJENJE KULTIVARA UKRASNIH JAPANSKIH JAVORA
}

\section{GRAFTING CULTIVARS OF DECORATIVE JAPANESE MAPLES}

\author{
Damir DRVODELIĆ ${ }^{1}$, Milan ORŠANIĆ
}

\begin{abstract}
SAŽETAK
U članku se govori o značaju ukrasnih japanskih javora u projektima krajobraznog uređenja prostora i njihovoj velikoj varijabilnosti. Detaljno je objašnjena metoda proizvodnje podloga iz sjemena i tehnika bočnog cijepljenja koja se provodi u zaštićenim prostorima krajem zime. Objašnjeni su svi čimbenici koje treba uzeti u obzir prije, za vrijeme i nakon cijepljenja. U članku su pojašnjene oznake koje se koriste u rasadničkoj proizvodnji cijepova, a preuzete se iz standarda europske udruge rasadničara - European Nurserystock Association (E.N.A.). Ovaj stručni rad može poslužiti svim rasadničarima, ali i pojedincima koji si sami žele razmnožiti određeni kultivar japanskog javora.
\end{abstract}

KLJUČNE RIJEČI: podloga, plemka, bočno cijepljenje, njega cijepova, E.N.A. standard

Japanski javor (Acer palmatum) je listopadna drvenasta biljka. Latinski naziv Acer znači šiljat, što upućuje na njegove listove šiljatih režnjeva, dok palmatum znači dlanast, što upućuje na karakterističnost listova koji su rašireni poput ljudskog dlana. Pripada u skupinu drveća niskog rasta. Najbolje se prepoznaje u jesen po atraktivnim i očaravajućim crvenim listovima.

Postoji više stotina kultivara ove vrste s vrlo velikom raznolikošću u konačnoj visini, brzini rasta, boji lišća i habitusu tj. obliku krošnje. C. J. van Gelderen i D. M. van Gelderen (1999) u enciklopediji „Javori za vrtove“ opisuju veliku raznolikost vrsta i kultivara javora koji se koriste za sadnju u vrtovima. Japanski javor potječe iz Japana, Koreje, Kine i dijelova sjeveroistočne Azije gdje je poznata kao samonikla biljka. Kad se proširila diljem svijeta, poprimila je karakteristiku ukrasnog stabla koje se sadi u parkovima i posudama. U područjima iz kojih potječe, ovo stablo je simboliziralo inteligenciju, dok danas na njegov spomen mnogi pomisle samo na japanski javor kao dekorativnu biljku, kao nešto lijepo i atraktivno. Japan je također poznat po tome što je kultivirao ovu vrstu ponajviše od 1603. do 1867. godine. Iz tog razdoblja postoje pisani zapisi koji govore o čak 200 kultiviranih vrsta koje su Japanci sadili u svojoj bližoj sredini i divili im se prilikom njihova razgledavanja. Do danas su mnoge kultivirane vrste iz tog vremena izgubljene zbog svjetskih ratova koji su Japance natjerali na sječu tih stabala, kako bi se imali čime grijati u tim teškim vremenima. Mnoge kultivirane vrste su izgubljene zbog netočnih engleskih prijevoda japanskih poetičnih nazivlja za ovu vrstu. U Americi i Europi su japanski nazivi nerijetko krivo izgovarani ili zapisani, što je dovelo do krivog pamćenja, a znalo se dogoditi da su ti nazivi namjerno promijenjeni kako bi se lakše prodali potencijalnim kupcima (https:// www.vrtlarica.com/uzgoj-japanskog-javora/). Danas se u rasadnicima u Republici Hrvatskoj razmnožava oko 50 kultivara japanskog dlanastolisnog javora. Cijena cijepova uvelike ovisi o kultivaru. Oni rjeđi i koji se teško razmnožavaju prodaju se po cijenama oko sto eura, dok je za većinu kultivara ta cijena dosta niža (http://www.sumins.hr/odjel-rasadnicke-proizvodnje).

\footnotetext{
'Doc. dr. sc. Damir Drvodelić, Šumarski fakultet Sveučilišta u Zagrebu, Svetošimunska 25, 10000 Zagreb, email: ddrvodelic@inet.hr
}

${ }^{2}$ Prof. dr. sc. Milan Oršanić, Šumarski fakultet Sveučilišta u Zagrebu, Svetošimunska 25, 10000 Zagreb 
Za zimsko cijepljenje brojnih vrlo dekorativnih kultivara japanskih javora potrebo je imati:

1 - Godišnje generativne podloge dobi 1+0 ili 1/0

2 - 1- godišnje plemke uzete $s$ etiketama označenih matičnih stabala u matičnjaku rasadnika

3 - Supstrat za punjenje kontejnera

4 - Grijani zaštićeni prostor

5 - Čisti stol i ergonomski stolac za osobu koja cijepi

6 - Alat i pribor za cijepljenje (voćarski nožić, voćarske škare, $96 \%$-postotni alkohol etanol, vata, materijali za učvršćivanje mjesta spoja, voćarski vosak, precizne škare ili pincete za skidanje (čišćenje) izbojaka ispod mjesta spoja, etikete i printer za pisanje ili barem vodootporni marker)

7 - Teoretsko znanje o kultivarima i tehnikama cijepljenja

8 - Praktično znanje koje se dobije ponavljanjem iste tehnike cijepljenja

9 - Umjetničke sklonosti

10 - Volja za radom i stvaranjem novih jedinki različitih uzgojnih oblika

11 - Vanjski prostor za aklimatizaciju cijepova

O brojnim čimbenicima koji utječu na uspjeh cijepljenja piše Jemrić (2007).

Podloge za cijepljenje brojnih kultivara japanskog javora (Acer palmatum) moraju biti jednogodišnje ili dvogodišnje (Dirr i Heuser, 1987) i uzgojene sjetvom sjemena (generative podloge) sakupljenog s tipične vrste Acer palmatum. Sjeme se može sijati na tri načina:

1 - Najjeftijiji način je proizvodnja sjemena na uzdignutim vanjskim gredicama ukoliko je rasadničko tlo povoljno za uzgoj navedene vrste

2 - Najstariji način, preuzet iz cvjećarstava i povrćarstva je uzgoj sadnica sjetvom u pojedinačne lončiće volumena od 1,4 do 21 ili multikontejnere od čvrste ili biorazgradive plastike.

3 - Najbolji način proizvodnje generativnih podloga vrste Acer palmatum u Republici Hrvatskoj pokazao se u Dunemannovim lijehama koje svatko može napraviti, a korisne su iz razloga što se sadnice uzgajaju u povoljnom supstratu, postoji sustav zalijevanja i zaštite od direktnog sunca i kasnog proljetnog mraza. Navedni način proizvodnje je skuplji, ali sadnice pokazuju bolji rast i prirast.

Postupak sjetve sjemena obuhvaća četiri radnje:

- priprema tla za sjetvu

- priprema sjemena

- obavljanje same sjetve

- postupak nakon sjetve
Jesenska sjetva obavlja se kod sjemena:

a) koje tada dozrijeva i teško mu je očuvati klijavost (žir, bukvica, kesten, orah, jela,...)

b) koje karakterizira dugo razdoblje mirovanja zbog dormantnosti embrija (jasen, javor,...)

c) koje je dvostruko dormantno (lipa, dren,...).

Sjeme se dijeli s obzirom na sposobnost očuvanja u skupine Ortodox i Recalcitrant. Odgovarajući hrvatski nazivi za navedene skupine ne postoje. Vlaga se kod Ortodox sjemena može sniziti sušenjem na $10 \%$ ili manje, a sjeme se može čuvati na temperaturama ispod nule (subfreezing). Recalcitrant sjeme je ono kojemu se vlaga ne smije spustiti ispod $15-45 \%$, a sjeme se ne smije čuvati na temperaturama blizu smrzavanja.

Recacitrant sjeme je vrlo osjetliivo na postupke rukovanja. Najznačajniji predstavnik je rod Quercus koji pripada u skupinu suhih plodova s odrvenjenim perikarpom (čvrsta struktura).

Neki autori sjeme dijele s obzirom na sposobnost očuvanja u četiri skupine:

Pravo ortodox sjeme,

Sub ortodox sjeme,

Umjereno recalcitrat sjeme,

Tropsko recalcitrant sjeme.

Sjeme javora pripada u skupinu umjerenog recaltitrantnog sjemena

Sabiranje, predsjetvena priprema, ispitivanje laboratorijske klijavosti i sjetva sjemena vrste Acer palmatum Thunb.

Prema Dirr i Heuser (1987), klijavost sjemena vrste Acer palmatum Thunb. ovisi o provenijenciji, vremenu sakupljanja i predsjetvenoj pripremi. Sjeme treba sakupljati kada je zeleno ili crveno, odnosno prije nego se osuši na stablu. Svježe sakupljeno i posijano sjeme klije idućeg proljeća. Suho sjeme prije sjetve treba dva dana močiti u vodi temperature $43^{\circ} \mathrm{C}$, a zatim ga stratificirati u trajanju od 3 do 5 mjeseci. Dobru klijavost daje zeleno/crveno sakupljeno i očišćeno sjeme koje smo tretirali fungicidima te stratificirano u vlažnom tresetu na temperaturi od $4{ }^{\circ} \mathrm{C}$ u trajanju od 3 do 5 mjeseci. U jednom istraživanju suho sjeme iz Japana posijano u jesen proklijalo je tijekom razdoblja od 5 godina. Drugi čimbenik koji utječe na visok postotak klijavosti je dobro zdravstveno stanje sjemena. Rasadničari bi kad je u pitanju suho sjeme trebali ispitati vitalitet sjemena metodom rezanja (mehanička metoda). Prije sjetve, a nakon hladne stratifikacije preporuča se držanje sjemena u toploj vodi. Pokazalo se kako primjena GA nije značajno utjecala na klijavost sjemena. O generativnom razmnožavanju vrste Acer palmatum i predsjetvenoj pripremi pišu Young i Young (1992). 
Prema ISTA Pravilima za ispitivanje klijavosti, sjeme vrste Acer palatum ispituje se na podlozi od pijeska ili metodom na papiru. Temperatura klijanja je konstantna i iznosi 20 ${ }^{\circ} \mathrm{C}$. Prvo brojanje klijanaca obavlja se sedmog dana, a završno 21 dana. Prije stavljanja sjemena na ispitivanje klijavosti potrebno ga je stratificirati u trajanju od 4 mjeseca na temperaturi od $1-5^{\circ} \mathrm{C}$. Uklanjanje perikarpa prije testiranja utječe povoljno na klijanje sjemena. Dodatne preporuke za ovu vrstu uključuju izvođenje tetrazol testa ili ispitivanje vitaliteta sjemena metodom rastenja oslobođenih embrija.

Sjeme se u rasadniku prekriva anorganskim (kvarcni pijesak) ili organskim (treset, kompost, posebno pripremljena mješavina za sjetvu) supstratima koji moraju imati osobine da se ne zbijaju djelovanjem atmosferilija, da ne dolazi do razvoja pokorice te da se buduća klica može lako probiti kroz supstrat. Uz sve navedeno supstrati ne bi smjeli sadržavati sjeme korova niti drugih vrsta šumskog i hortikulturnog sjemena i ne smiju biti fitotoksični za sjeme i mlade biljčice. Sjeme se prekriva slojem supstrata dva do tri promjera sjemena na užem dijelu. Gredice poslije sjetve nije potrebno valjati.

\section{Rasadnčka tehnologija proizvodnje sadnica javora}

Preporuka je za većinu vrsta javora jesenska sjetva sjemena i malčiranje gredica. Stratificirano sjeme može se sijati u proljeće, ali su rezultati varijabilni i često nezadovoljavajući. Sjeme javora sije se na dubinu od 0,5 do $1,0 \mathrm{~cm}$. Sjetva se obavlja omaške ili u redovima. Preporuka je da gustoća sadnica na gredicama bude od 150 do $1500 \mathrm{komada} / \mathrm{m}^{2}$. Niža gustoća se preporuča za dobivanje biljaka visokog vigora. Zasjenjivanje gredica potrebno je tijekom klijanja i razvoja klijanca (3 tjedna). Ponekad su sadnice javora dovoljno velike da se uzgajaju kao $1+0$, ali ta dobivanje zadovoljavajućih rezultata često je potreban uzgoj $2+0$ ili $2+2$. Općenito, što su sadnice veće, preživljenje je bolje. Sadnice kultivara Acer palmatum 'Atropurpureum' uzgajaju se za dobivanje podloga za cijepljenje brojnih kultivara vrste Acer palmatum. U tom slučaju generativne podloge moraju bit starosti $2(2+0)$ ili više godina. Drugi razlog uzgoja je dobivanje sadnica kultivara koji će se prodavati pod nazivom Acer palmatum 'Atropurpureum' uzgojen iz sjemena. U tom slučaju radi se selekcija na pri kraju prve vegetacije kad biljke poprime crvenkastu boju lišća na način da se pročupaju biljke sa zelenom i prijelaznom bojom lišća. Selekcija po boji može se raditi u drugoj i narednim godinama uzgoja. Cilj je dobiti što veći postotak sadnica s crvenom bojom lišća u jesenskom razdoblju. Svojstva sadnica kultivara Acer palmatum 'Atropurpureum' uzgojenih iz sjemena je varijabilna boja lišća. Sadnice ne zadržavaju crvenu boju lista preko cijele vegetacije već samo pri kraju, što je razlika u odnosu na sadnice ovog kultivara uzgojenog cijepljenjem kod kojega je boja lišća stalno crvena tijekom cijele vegetacije.
Kod jesenske sjetve sjemena kultivara Acer palmatum 'Atropurpureum' u prethodno pripremljeni supstrat u Dunemannovim lijehama najprije se daskom ravnjačom treba poravnati površinski sloj supstrata kako bi svaka sjemenka imala podjednake uvjete za klijanje. Sjeme se sije omaške, razbacivanjem iz ruke pri čemu je važna homogena distribucija sjemena na sjetvenoj posteljici. Nakon sjetve, sjeme se prekriva specijalnim supstratom za sjetvu na bazi treseta nešto dublje nego kod proljetne sjetve, što znači oko $1 \mathrm{~cm}$. Nakon prekrivanja gredice treba malčirati listincem (otpalim lišćem) koje ne smije sadržavati sjeme vrsta sa kojih je list sakupljen. Malč će služiti kao zaštita sjemena od smrzavanja. Malčirana površina bit će toplija zimi i imat će manja kolebanja temperature za razliku od ne malčirane. U proljeće, čim biljčice počnu s klijanjem, malč se treba ručno ukloniti kako ne bi ometao rastu klijanaca zbog manjka svjetla (pojava izduživanja biljaka i etiolacija) te doveo do pojave zakrivljenih sadnica.

Za uzgoj jednogodišnjih generativnih podloga (oznaka $1+0$ ili 1/0) za cijepljenje, klijanci se pikiraju u fazi kad im se razvije prvi par listova normalne veličine. Čupanje klijanaca treba obaviti nakon kišnog razdoblja ili obilnog navodnjavanja. Klijanci se presađuju u centar kvadratičnih $(9 \mathrm{x} 9 \mathrm{~cm})$ lončića visine $20 \mathrm{~cm}$ i zapremine od 1,4 do 2,0 litre koji se pune mješavinom rasadničkog tla, crnog treseta i pijeska. Prema E.N.A. standardu lončići se označavaju početnom oznakom P iza koje slijedi širina lončića od 5-13 cm, npr. P9 znači širina lončića od $9 \mathrm{~cm}$. Lončići (do 21 volumena) bi trebali imati otvore na dnu zbog odvodnje suviška vode i sa strane zbog zračnog podrezivanja ili desikacije korijena. Nakon presadnje obavezno je zalijevanje lončića sve dok se

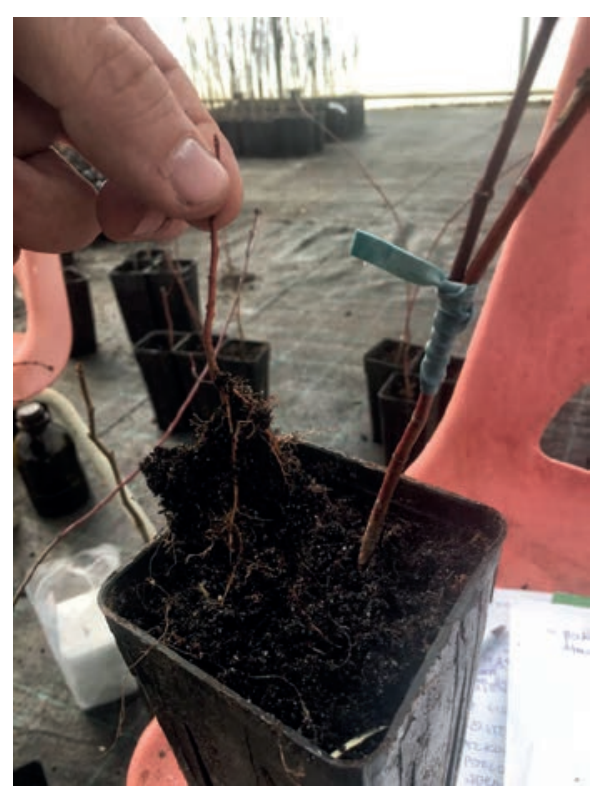

Slika 1. Pročupavanje manje sadnice vrste Acer palmatum u lončiću i ostavljanje deblje kao podloge za cijepljenje

Figure 1. Plucking a smaller Acer palmatum seedling into a pot and leaving it thicker as a grafting rootstock 


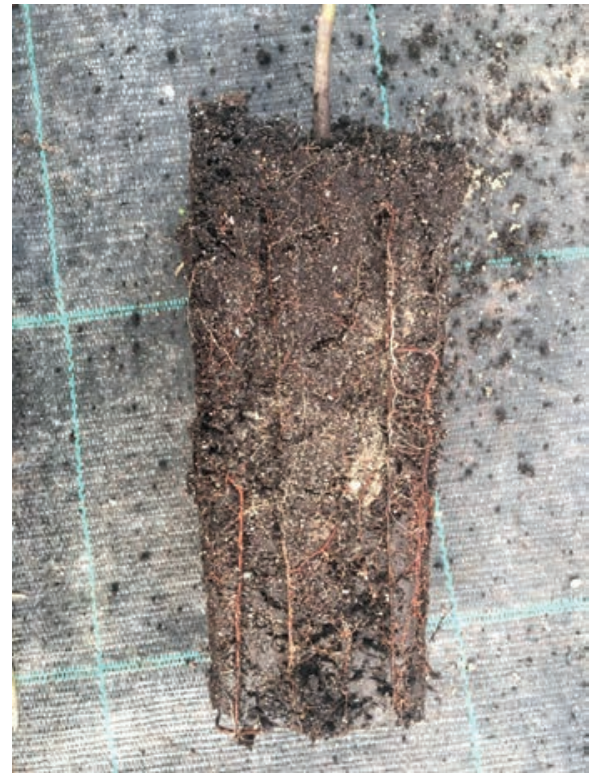

Slika 2. Aktivacija korijena podloge sadnice vrste Acer palmatum vidljiva je po bijelim sitnim korjenčićima

Figure 2. Activation of rootstock roots of Acer palmatum seedlings is visible on white small roots

ne primijeti otjecanje vode kroz otvore na dnu. Lončići se drže u prvo vrijeme pod zasjenom oko $50 \%$, a nakon toga u uvjetima svjetla uz osigurano navodnjavanje ili zalijevanje. Na kraju prve vegetacije podloge mogu izrasti više od pola metra i imati dovoljne promjere za cijepljenje većine vrste javora. Korijenski sustav podloge je prorastao raspoloživi volumen lončića i sadnice se mogu vaditi bez rasipanja supstrata. Ukoliko se u lončić posije više sjemenki zbog njegove dvostruke dormantnosti i sigurnosti, ponekad se dogodi da se razvije jedna biljka normalne veličine i još jedna manja zbog naknadnog klijanja, tu manju treba obavezno ukloniti pročupavanjem s korijenom (slika 1.), a ne prorezivanjem stabljike u području vrata korijena škarama, jer se u ovom drugom slučaju ispod mjesta reza opet mogu aktivirati izbojci iz spavajućih pupova.

Početkom siječnja podloge se unose u grijani zaštićeni prostor i slažu jedna do druge kako bi zauzimale što manju površinu. Zalijevati treba kad se supstrat lagano prosuši. Nakon otprilike mjesec dana korijen se počinje prvi aktivirati, što se vidi po novim sitnim bijelim korjenčićima (slika 2).

To nam je znak da će ubrzo krenuti biljni sokovi prema izbojcima i da će se moći ubrzo pristupiti cijepljenju. Pošto je korijen podloge prorastao supstrat sadnica se može normalno vaditi iz lončića, a da ne dođe do rasipanja supstrata i oštećivanja korijena. Slijedi bubrenje lisnih pupova i pojava novih listića. Kad se to dogodi može se pristupiti samom cijepljenju koje se izvodi u zaštićenom prostoru.

Najčešće se koriste generativne podloge uzgojene sjetvom sjemena u Dunemannove lijehe, $\mathrm{u}$ fazi klijanca presađene u lončiće i stare jednu vegetaciju kad su spremne za cije- pljenje. U slučaju da je podloga svježe sađena u lončić, može se cijepiti odmah, ali se obavezno cijep mora ostaviti jednu vegetaciju u lončiću kako bi korijenski sustav ispunio raspoloživi volumen supstrata. Takvi cijepovi se mogu nakon cijepljenja izvaditi na otvoreno, ali se ne smiju presađivati niti u veće kontejnere niti na polje.

Prema E.N.A. standardu, podloge za cijepljenje su od godinu do dvije stare biljke, mogu biti proizvedene iz sjemena ili vegetativno. Dijele se na podloge proizvedene iz sjemena: sjemenjaci, orezani sjemenjaci i presađeni sjemenjaci i na vegetativno proizvedene podloge: grebenice i mekane i tvrde reznice. Sjemenjaci na prvotnom položaju ili jednogodišnji sjemenjaci imaju oznaku $1 / 0$ (klijanci in situ) i to su biljke iz sjemena, koje nisu presađivane i obično imaju jedan glavni korijen. Sjemenjaci presađeni u stadiju kotiledona ili supki nose oznaku $1 / x 0$ što je najčešći slučaj kod podloga vrste Acer palmatum.

Plemke se uzimaju isključivo s etiketiranih matičnih biljaka kultivara japanskog javora u matičnjaku rasadnika i to za vrijeme dok su u fazi potpunog mirovanja. Matične biljke treba saditi na srednje humusnom tlu u rasadniku i na njima provoditi sve uzgojne mjere (orezivanje, umjereno navodnjavanje i ciljana prihrana, zaštita od biljnih bolesti i štetnika i dr.), a samu površinu oko biljaka treba malčirati i čupati korov ukoliko se pojavi kroz malč. Između redova površinu treba obrađivati frezanjem, pri čemu treba paziti da se tlo previše ne usitni i ne naruše mu se strukturni agregati, jer je u tom slučaju sklono stvaranju pokorice i površinskom otjecanju vode. Treba provoditi redoviti monitoring na svim biljkama u matičnjaku. Jako je važno da svaka biljka ima na sebi etiketu s punim latinskim nazivom kultivara i podacima o uzgoju. Svaki kultivar u matičnjaku mora bit zastupljen u barem tri primjerka. Razmak između kultivara ovisi o njihovom habitusu brzini rasta i sl. Na to posebno treba obratiti pažnju. Dosta kultivara japanskog javora najbolje uspijeva u uvjetima blagog difuznog svjetla, dok se drugi trebaju saditi na potpunom suncu kako bi zadržali tipičnu boju lišća svojstvenu za taj kultivar (npr. tamno crveno i crveno lišće). Kod onih koji su osjetljivi na direktno sunce, događaju se rubne spržotine lišća što može dovesti i do slabijeg prirašćivanja i ranije defolijacije, a narušava se i estetski izgled. Japanski javori ne vole propuh i kanalizaciju vjetra, a većina njih je osjetljiva i na kasne proljetne mrazove (do 15.5.). Ukoliko se dogode mrazovi, a izbojci su se jako razvili obavlja se zaštita od mraza navodnjavanjem odozgo u ranim jutarnjim satima. Za zaštitu od mraza može se koristiti prekrivanje matičnjaka javora agrotekstilom (kovertin agril, lutrasil i sl.). Ovisno o kultivaru, japanski javori imaju različite debljine plemki koje se mogu uzeti, pa je nužno imati i podloge odgovarajuće debljine. Plemke se uzimaju za vrijeme mirovanja vegetacije dok su pupovi u fazi najdublje dormantnosti i odmah se stavljaju u PVC vrećice s vlažnim pijeskom koji služi za čuvanje vlage 
i drže se u hladnjačama ili frižiderima (ovisno o količinama i raspoloživosti). Plemke se ne smiju osušiti. Kod uzimanja plemki voćarskim škarama treba obratiti pažnju da su one zdrave, što se vidi na samom presjeku. Ponekad kod nekih kultivara japanskih javora niske zimske temperature i rani jesenski mrazevi mogu dovesti do sušenja vrhova izbojaka ili cijelih izbojaka. Svaki kultivar japanskog javora ne podnosi klimatske uvjete koji su na području Republike Hrvatske i na to treba obratiti posebnu pažnju kod kupnje biljaka za matičnjak i njihovom daljnjem razmnožavanju. Zbog isušivanja plemki uvijek je dobro uzeti nešto veće izbojke. Samo cijepljenje izvodi se s plemkama starim jednu godinu koje mogu imati terminalni pup ili se uzete iz sredine izbojka. Važno je ponekad i povećalom ili lupom obratiti pažnju na stanje pupova na plemci, jer oni moraju biti zdravi i u stanju mirovanja. Svaka plemka trebala bi imati od 5 do 7 zdravih pupova koji su kod ove vrste i kultivara na izbojku raspoređeni nasuprotno. Kad se koriste plemke iz srednjeg dijela izbojka gornji rez se reže oko pola $\mathrm{cm}$ iznad nasuprotnih pupova pod kutom od $90^{\circ}$ ili ravno.

Cijepljenje se obavlja nakon mjesec dana od unošenja podloga u grijani zaštićeni prostor, a to znači početkom veljače. Za dobro kalusiranje važna je visoka temperatura zaštićenog prostora od 20 do $25^{\circ} \mathrm{C}$ i visoka relativna zračna vlaga. Cijepljene biljke također trebaju biti na svjetlu. Kod cijepljenja je važno da jedna osoba cijepi samo jedan kultivar i nakon cijepljenja se na svaku sadnicu odmah stavlja etiketa. Nakon što se pocijepe sve plemke, ide se s cijepljenjem drugog kultivara kako ne bi došlo do zabune, jer pojedini kultivari imaju dendrološki gledano vrlo slične izbojke, pupove, lenticele i lišće. Održavanje sto postotne klonske čistoće je vrlo bitno. Prije cijepljenja treba se nabaviti čisti stol i stolica koji moraju biti ergonomski prilagođeni osobama koji cijepe. Posebnu pažnju treba obratiti na položaj kralješnice kod cijepljenja o čemu trebaju voditi brigu voditelji rasadnika. Pošto je cijepljenje način rada gdje se isti postupci ponavljaju, treba stvoriti ugodnu atmosferu između osoba i u prostoru se može puštati određena glazba kako bi se razbila monotonija, a ponajviše da ne dođe do psihičkog zamora ljudi, što neminovno dovodi do grešaka u tehnici cijepljenja i na kraju malog postotka primanja. Vrlo česte pogreške kod cijepljenja povezane su s lošim ergonomskim položajem osoba koje cijepe i lošim sanitarno-higijenskim uvjetima. Podloga ili stol gdje se drže plemke mora biti čista.

Ovakav način zimskog cijepljenja japanskih ukrasnih javora u zaštićenim prostorima obavlja se tehnikom bočnog cijepljenja s neprevršenom podlogom (slika 3.). O samoj tehnici bočnog cijepljenja pišu mnogi autori poput MacDonalda (1986), Stilinovića (1987), Dirra i Heusera (1987) i Međedovića i Ferhatovića (2003) i dr.

$\mathrm{Na}$ isti način se tradicionalno cijepe četinjače, ali i mnoge ostale vrste ukrasnog drveća i grmlja. Prije početka cijepljenja treba uzeti plemke samo jednog kultivara iz hladnjače

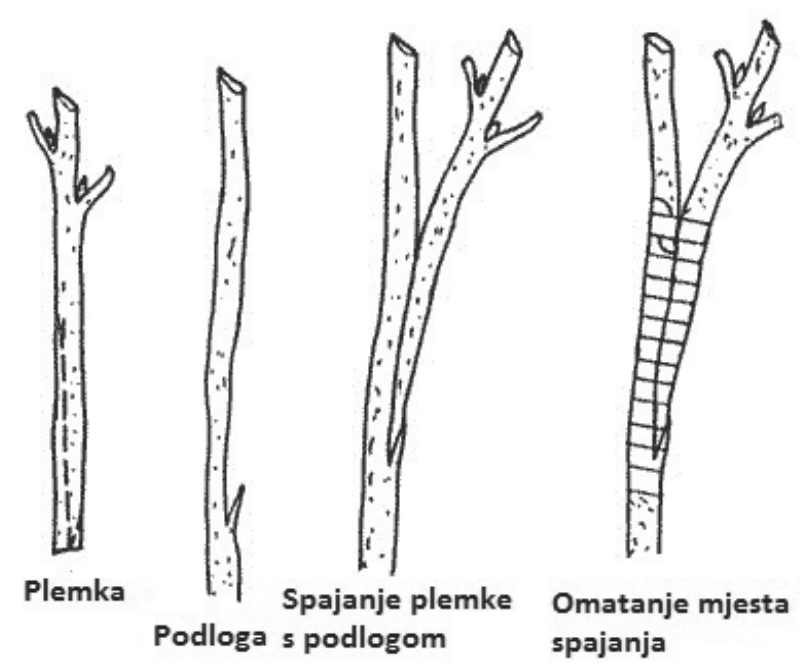

Slika 3. Shematski prikaz tehnike bočnog cijepljenja s neprevršenom podlogom

Figure 3. Schematic illustration of the side-veneer grafting technique with uncut rootstock

i pripremiti alat i pribor u što pripadaju voćarski nožić, voćarske škare, precizne škare ili grickalice za skidanje sitnih pupova na podlozi ili plemci koji smetaju pri izvođenju cijepljenja, ali i kasnije čišćenje ili skidanje izbojaka na podlozi ispod mjesta spajanja koji se vrlo često aktiviraju iz spavajućih pupova, a štetni su jer troše biljne sokove i ne raspoređuju je u plemku u dovoljnoj količini (slika 4). O razmnožavanju brojnih ukrasnih formi japanskog javora cijepljenjem piše Stilinović (1987) pri čemu navodi kako je moguće bočno cijepljenje, u kolovozu odnosno u rano proljeće, pod staklom.

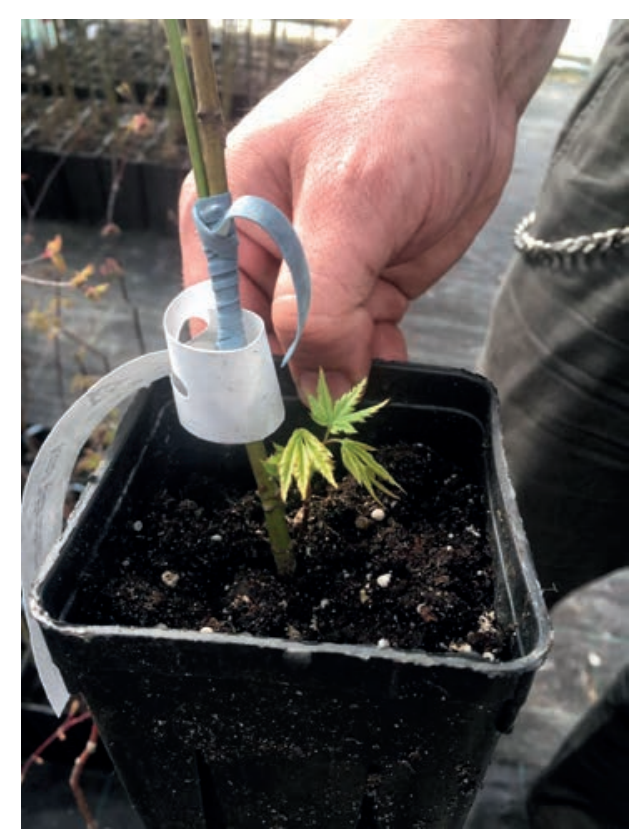

Slika 4. Aktvirani izbojci iz spavajućih pupova ispod mjesta cijepljenja koje treba odmah ukloniti

Figure 4. Activated shoots from sleeping buds below the grafting site to be removed immediately 
$96 \%$-postotni alkohol etanol koristi se za dezinfekciju alata i pribora te plemki i podloga. Dezinficirana vata umače se u alkohol. Jako su važni elastični i dosta široki materijali za učvršćivanje mjesta spoja poput gumica raznih boja (plava, crvena,...), prozirne „strech“ folije širine od 3-5 mm ili bilo kojeg materijala od platna i sl. Sama rafija nije toliko dobra jer nije elastična i može se zbog kasnije nebrige usjeći u drvo, posebno kod vrsta koje imaju vrlo jak radijalni prirast. Treba imati i voćarski vosak iako ga mnogi rasadničari ne koriste jer usporava proces, a ukoliko nije kvalitetan njegova primjena može imati i negativne posljedice. Naime, loš vosak se često raspucava, a na površini koju treba štititi od vlage čini kontra ekekt, što je idealno mjesto za mogući ulazak spora patogenih gljiva koje se u uvjetima povećane temperature i vlažnosti ispod voska vrlo brzo razmnožavaju i mogu dovesti do truleži drva. Ako se koristi dobar vosak s njim se premaže gornji vodoravni rez na plemci i materijal za učvršćivanje nakon omatanja i to potpuno, a posebno treba voditi brigu da se voskom zalije i gornji dio na plemci koje je u kontaktu s podlogom, jer je to najčešći mogući ulazak vlage od navodnjavanja, ali i zračne vlage. Odmah nakon cijepljenja jednog kultivara na svaku sadnicu se stavlja etiketa s točnim latinskim imenom kultivara (slika 5.).

Najbolje su bijele etikete zbog manjeg sunčevog zagrijavanja i dulje trajnosti koje su ispisane uz pomoć printera i softvera za pisanje etiketa. Prednosti printanja etiketa su što na njih stane više informacija i možemo ih kreirati po vlastitoj želji (logo institucije itd.) za razliku ako se po njima piše vodootpornim markerom koji se ima negativne strane zbog lošeg rukopisa pojedinih osoba i brisanja slova nakon izlaganja vlazi i ostalim vanjskim čimbenicima. Najboljim

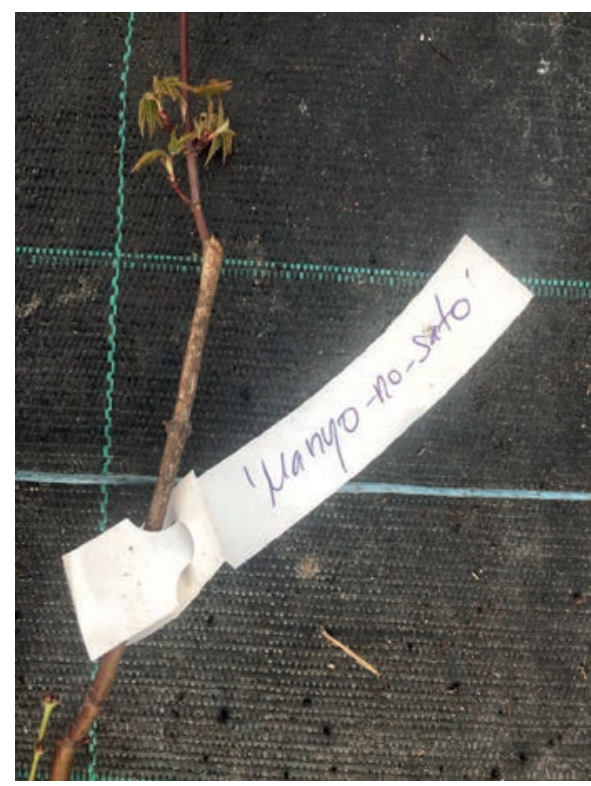

Slika 5. Obavezno stavljanje etikete na svaku sadnicu s točnim latinskim nazivom kultivara obavlja se odmah nakon cijepljenja

Figure 5 . The necessarily labeling of each seedling with the correct latin cultivar name is done immediately after grafting

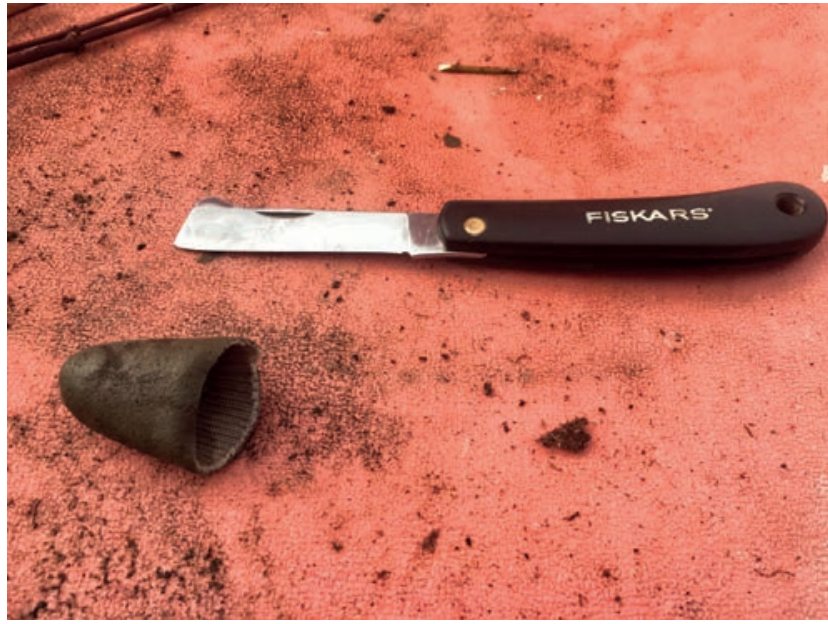

Slika 6. Nožić za tehniku bočnog cijepljenja naoštren samo s jedne strane

Figure 6. Knife for side-veneer grafting technique sharpened on one side only

se pokazao crni vodootporni marker s ušiljenim vrhom. Sav alat i pribor za cijepljenje trebao bi biti profesionalan i na tome ne treba kod kupnje niti malo štedjeti, jer se neki alati mogu koristiti puno godina. Dobro je da svaka osoba koja cijepi ima svoj vlastiti alat i pribor. Kod cijepljenja je posebno važna čistoća alata i pribora te oštrina nožića i škara. Nožići za bočno cijepljenje trebali bi biti naoštreni samo s jedne strane, a ne s obje (slika 6.).

Oštrim krakom reže se rez na podlozi i plemci. Neke osobe rade više s lijevom rukom pa na to treba obratiti također pozornost. Ukoliko nožić nije oštar niti sam rez ne može biti oštar i nije ga moguće napraviti u jednom potezu.

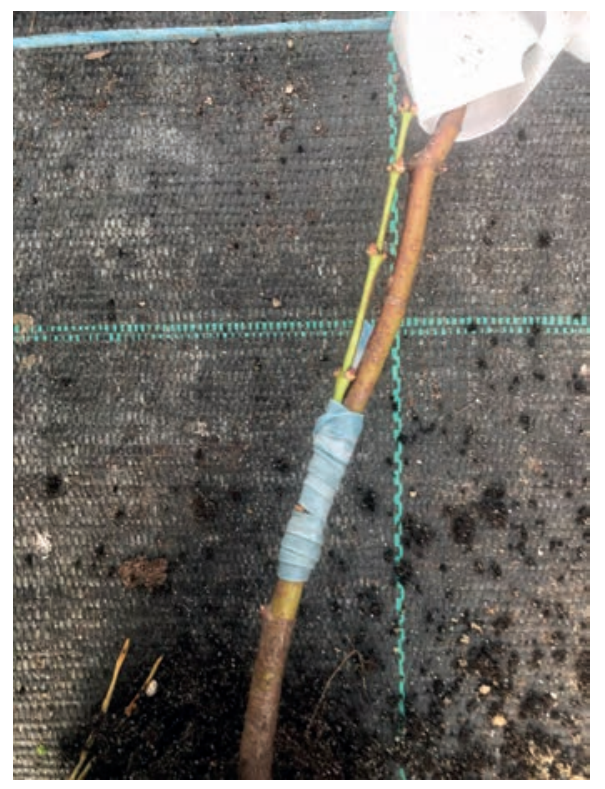

Slika 7. Prikaz zakrivljene podloge i pravilnog (lakšeg) izvođenja cijepljenja na konveksnoj strani

Figure 7. View of the curved rootstock and proper (easier) perform of the grafting on the convex side 
Tehnika bočnog spajanja kronološki se izvodi na sljedeći način:

- Uzimaju se podloge i do mjesta spajanja orezuju se primarne grančice ukoliko ih ima. Treba paziti da se ne ošteti kora, a posebno živi dio kore na podlozi.

- S obzirom na debljinu plemke odredi se mjesto spajanja. To je najpraktičnije odrediti uzimanjem u ruke plemku i uspoređivanjem s debljinom podloge. Tamo gdje je njihova debljina ista ili približno ista obavit će se cijepljenje.

- Vatom natopljenom u alkoholu podloga se do mjesta spajanja i malo više od toga dezinficira i očisti od moguće prljavštine.

- Najbolje su ravne podloge, jer je na njima najlakše cijepiti s obzirom na stranu. Kod zakrivljenih podloga, cijepljenje je iz praktičnih razloga najbolje obaviti s konveksne strane, a ne s konkavne ili udubljene, jer će se plemka teško spajati (slika 7.).

- Plemku treba doraditi s obzirom na broj pupova i ukoliko ima suhi ili smrznuti vrh onda se taj mrtvi dio reže do zdravog dijela.

- Lončići se pridržavaju između nogu kako bi bili stabilni kod samog cijepljenja. Za zaštitu radnog odijela radnika od prljavštine mogu lončići se mogu omotati PVC folijom ili tkaninom, iako to može ponekad samo smetati. Prije rezanja podloge na palac se stavi tzv. „napršnjak“ (slika 8.) kako bi se radnik zaštitio od mogućih posjekotina. To se može napraviti od starih kožnih rukavica, rezanjem vrhova tako da svojom dužinom prekrivaju cijeli palac. Drugi način je višestruko omatanje palca gazom,

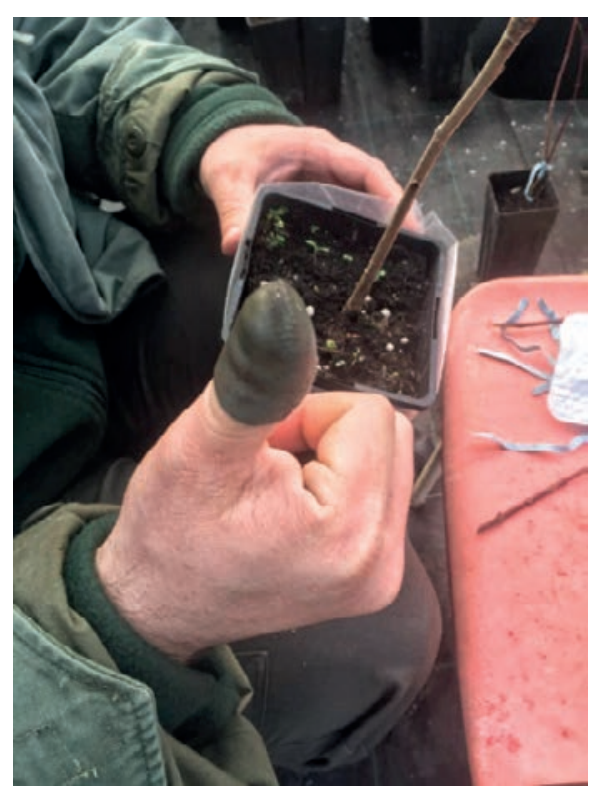

Slika 8. Stavljanje „napršnjaka“ kao zaštita palca od mogućih ozljeda oštrim nožićem

Figure 8. Put on of the "thimble" as protection of the thumb from possible injuries with a sharp knife tkaninom ili tzv. flasterom Hansaplast, ali to je puno lošije jer u procesu cijepljenja to mnogim ljudima smeta, posebno kod omatanja mjesta spoja. Zaštita palca od ozljeda je neophodna, jer ozljede ponekad mogu biti vrlo teške zbog oštrine nožića i mogu se dobiti duboke posjekotine koje jako krvare zbog završetka brojnih živaca u prstima. Ujedno napršnjak služi za fiksiranje plemke kod izvođenja reza, a sam rez ide direktno prema palcu.

- Prvo se radi u jednom potezu rez na podlozi koji smo prethodno definirali. Rez se izvodi odozgo prema dolje što je više moguće paralelno $s$ istom stranom stabljike. Nije dobro u gornjem dijelu rez raditi s udubljenjem tj. blago konkavnim nagibom, jer će plemka u tom slučaju loše prionuti uz podlogu. Rezom se skida mrtvi tj. vanjski dio kore i dolazi se do kambija. Prvi rez je najbolje napraviti u jednom potezu u duljini od 3 do $5 \mathrm{~cm}$, nakon čega se radi s donje strane drugi rez tako da se napravi jezičak u koji će naleći plemka. Taj jezičak bi trebao biti otprilike oko $0,5 \mathrm{~cm}$. Kratki jezičci nisu dobri. Ukoliko se napravi kraći jezičak on se može naknadno popraviti s nožićem lagano prema dolje.

- Na plemci se napravi rez istovjetan onom na podlozi, najbolje u jednom potezu, odozgo prema dolje. Plemka mora biti klinasto ušiljena, a to znači kad se dođe do polovice, rez mora ići drastično prema bazi ili donjem dijelu plemke. Sa suprotne strane toga reza napravi se još mali rez od 0,5 cm koji će naleći svojim dijelom na jezičak.

- Omatanje mjesta spoja obavlja se odozdo, pri čemu treba paziti da se počne ispod jezička na koji je nalegla plemka. Prvo treba elastičnu gumicu odozdo fiksirati prstima i napraviti nekoliko prvi jakih namotaja koji se izvode rastežući gumicu do kraja. Slijedi omatanje gumicom po cijeloj dužini mjesta spajanja, na način da se gumica preklapa po polovici širine a ujedno se promatra da plemka s obje strane naliježe na kambijalni dio podloge što je vrlo važno. Omotati treba skroz do kraja pri čemu se zadnji omotaj gumice treba dobri fiksirati da se gumica ne odvoji i mjesto cijepa oslabi (slika 9.).

- Omatanje se obavlja bez tzv. „napršnjaka“ jer smo komotniji pri samom radu.

- Nakon omatanja vrh reza plemke i gumica se oblažu s voskom koji ima funkciju poticanja kalusiranja i bržeg spajanja provodnih elemenata podloge s plemkom, sadrži određena fungicidna svojstva te sprječava ulazak vode, spora gljiva i mikroorganizama na mjesto spajanja.

- Prije cijepljenja podloga se zalijeva tek kad se supstrat lagano prosuši, a nakon cijepljenja sadnice treba jače zalijevati.

- Ovakav način bočnog cijepljenja ukrasnih kultivara japanskih javora moguće je, u slučaju dobre obučenosti izvesti metodom od samo 4 reza, svaki u jednom potezu. 


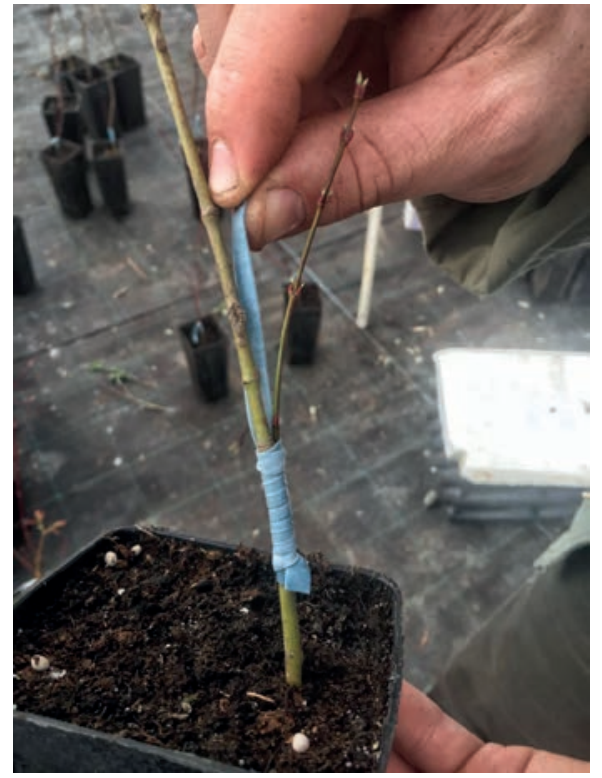

Slika 9. Princip učvršćivanja mjesta spoja podloge i plemke s omatanjem elastičnom gumicom

Figure 9. Principle of fixing the junction of the rootstock and scion with the elastic band wrapper

- Svi izbojci koji se aktiviraju ispod mjesta cijepljenja moraju se odmah uklanjati tj. čistiti, najbolje grickalicama ili specijalnim škarama na način da se ne ošteti kora podloge. Cilj je biljne sokove ponajprije usmjeriti u plemku kako bi što prije potjerala. Taj proces se događa zbog različitog fiziološkog stanja podloge i plemke. Snažni biljni sokovi koju usvaja fiziološki aktivna podloga usmjeravaju se na fiziološki neaktivnu plemku. Na slici 10. prikazan je izgled sadnica japanskih ukrasnih javora odmah nakon provedenog cijepljenja.

- Otprilike mjesec dana nakon cijepljenja i čuvanja sadnica $\mathrm{u}$ istom grijanom prostoru, ukoliko je plemka potjerala i

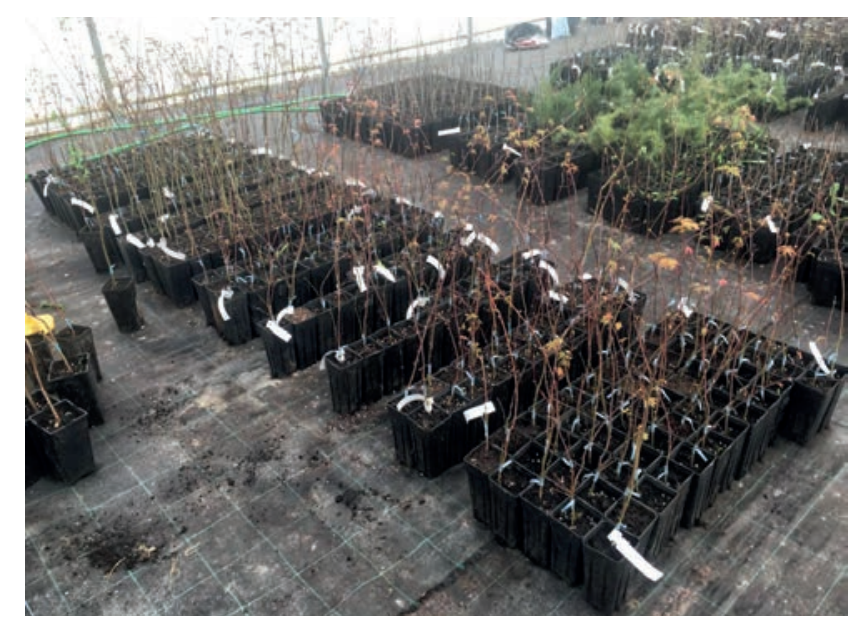

Slika 10. Sadnice japanskih ukrasnih javora snimljene nakon provedenog cijepljenja

Figure 10. Decorative japanese maples seedlings photographed after grafting razvili su se listovi, može se načiniti rez da se prevrši podloga. Taj rez se radi nekoliko centimetara iznad mjesta spajanja i pod kutom od $45^{\circ}$, suprotno od plemke kako voda ne bi ulazila u mjesto spajanja. Kad smo sigurni da se plemka dobro primila i počela s intenzivnim rastom, skidamo gumicu i radimo rez na podlozi nekoliko $\mathrm{mm}$ iznad samog mjesta spajanja. Nije dobro raditi rez na samom mjestu spajanja, jer se u tom slučaju taj dio može mehanički oslabiti i odlomiti, a s druge strane ne dozvoljava se normalno kalusiranje. Na cijepovima je uvijek vidljivo mjesto spajanja, a vrlo često i sama tehnika spajanja koja se može uočiti do kraja života cijepa. Ponekad se na mjestu cijepa stvori nateknuće zbog izrazitog rasta meristemskih stanica, a to se naziva guka.

- Prema E.N.A. standardu cijep je biljka nastala iz baznog cijepa, na kojoj mladica sa jednogodišnjim vegetativnim porastom produžuje podlogu, te na kojoj su sa mjesta cijepa, nakon dobrog srastanja, skinuti pomoćni materijali korišteni za učvršćivanje. Ili biljka koja je bila povratno orezana do mjesta cijepa, te novim izdancima produžuje podlogu.

- Cijep je nakon toga iznosi iz zaštićenog prostora u vanjske uvijete, ali ne odmah na direktno sunce, već pod djelomičnu umjetnu zasjenu (razna sjenila) ili difuzno svjetlo krošanja velikih stabala. Taj proces se naziva aklimatizacija cijepa.

- Nakon aklimatizacije cijepovi se, ovisno opet o kultivaru, mogu držati na svjetlu i ostaju u istom lončiću do kraja vegetacije.

- Nakon završetka prve vegetacije postoje dvije opcije za daljnji uzgoj cijepa. Prva i skuplja, ali višestruko ekonomski isplativija metoda je presadnja cijepa iz lončića u veći kontejner (volumen veći od 2 litre, npr. C4=volumen 4 litre) i kontinuirana presadnja sve do prodajnih dimenzija prema određenim i prihvaćenim rasadničkim standardima. Kod presadnje treba voditi brigu se ne cijep ne presađuje odmah u kontejnere velikih zapremina već postupno, što pogoduje uravnoteženom rastu biljke (korijen vs krošnja). Supstrat i gnojivo kojima se pune kontejneri trebaju biti ciljani za pojedini kultivar. Navodnjavanje kapaljkama je obvezno, kao i malčiranje površine kontejnera s borovom korom ili pijeskom zbog pojave korova.

- Drugi način je presadnja cijepa na otvoreno u prethodno pripremljena polja u rasadniku, pri čemu treba voditi računa da li se kultivari drže na svjetlu ili polusjeni te o razmaku između biljaka, što opet ovisi o željenoj ili konačnoj visini kultivara, obliku kultivara (stupasti, u obliku uže ili šire vaze, viseći, kuglasti, usko ili široko kišobranasti). Ukoliko je jednogodišnja podloga dobro prorasla raspoloživi volumen lončića, nakon cijepljenja cijep se može presaditi u svibnju i lipnju iste godine nakon cijepljenja. Opasnost mogu biti visoke temperature i manjak vlage, pa je po- 
trebno obvezno osigurati navodnjavanje. Kod nekih kultivara cijep treba biti usidren s rasadničkim uzgojnim kolcem na način da se omogući lagano gibanje stabljike vjetrom, čime se postiže povećanje promjera debla i njegova stabilnost nakon sadnje na terenu, a ne čvrsto uz samu stabljiku, jer se dobivaju visoke a vitke sadnice bez pada promjera i takve će trebati sidrenje nakon sadnje na terenu.

- Voditelj rasadnika treba voditi brigu o kompletnom tehnološkom procesu proizvodnje cijepova, a posebno o trenutku unošenja u zaštićene grijane prostore, određivanju početka cijepljenja za svaki kultivar posebno te vođenje evidencije o postotku primitka pojedinog kultivara. Dobro je evidenciju voditi i po osobi koja obavlja cijepljenje, jer je ono interakcija teoretskog znanja stečenog prethodnim učenjem i proučavanjem literature, vještina i brzina rada koja se stječu ponavljanjem istih operacija, umjetničkim sklonostima za stvaranjem neobičnih oblika cijepljenja, a posebno strpljenja i volje. Rezultati primitka mogu značajno varirati ovisno o osobi koja obavlja cijepljenje. Često su potrebe za takvim osobama u deficitu u odnosu na raspoložive količine podloga za cijepljenje.

- E.N.A. standard koristi šifre za cijepljene mlade sadnice (cijepove) kao što su npr. X/1/0: jednogodišnja cijepljena sadnica; X/2/0:dvogodišnja cijepljena sadnica; $\mathrm{X} / 0 / 1$ jednogodišnja presađivana cijepljena sadnica i $\mathrm{X} / 1 / 1$ : dvogodišnja presađivana cijepljena sadnica. Mlade sadnice proizvedene cijepljenjem označene su simbolom ' $x$ ' kao prvim. Drugi simbol, nakon ' $x$ ', označava broj godina koliko je biljka rasla u mjestu nakon cijepljenja. Treći simbol označava broj godina koliko je cijepljena biljka uzgajana u rasadniku nakon presađivanja ili premještanja iz posude u posudu.

Japanski javori vole plodna, umjereno vlažna i blago kisela tla. Ne podnose jake vjetrove i odgovaraju im sunčani do polusjenoviti položaji. Često se uzgajaju u privatnim vrtovima, posebno onim manjim, alpinetumima ili kamenjarama ili u parkovima. Svojim atraktivnim i raznolikim bojama unose estetiku i živost u prostor. Može se saditi u kombinaciji s drugim biljkama, poput grmlja i nižih drvenastih biljka, ali najljepši je kada se sadi pojedinačno, izoliran od ostalih vrsta. Kod odabira mjesta sadnje, najbolje je kultivare zelenih listova posaditi na područja s popodnevnom sjenom, kultivare prošaranih listova na polusjenovita područja, a kultivare crvenih listova na područja koja barem pola dana pružaju izravnu sunčevu svjetlost (inače listovi gube prepoznatljivu crvenu boju). Pažnja se mora obratiti i na područje oko debla koje mora biti bez podrasta i bez obrasle trave koja može stablu onemogućiti normalan dotok vode i hranjivih tvari. U slučajevima velikih ljetnih vrućina ili niskih temperatura popraćenih naletima hladnog vjetra, kao posljedica se može dogoditi fiziološka palež lišća. Zalijevanje japanskog javora na vlažnom tlu je najbolje vršiti rano ujutro ili navečer, a u slučaju suhog tla, prvo se treba osmisliti kako zadržati vlagu u tlu da ne dođe do isušivanja. Neka od rješenja su zastiranje tla ili malčiranje. U Hrvatskoj uspijeva i u mediteranskoj i u kontinentalnoj klimi, na vlažnom i blago kiselom tlu koje ne smije biti prebogato humusom. Također je moguć uzgoj japanskog javora na nepogodnijem tlu, ali tada će bilika izrasti niže od svojeg prosjeka. Vrste koje narastu kod nas su nešto niže od onih koje rastu u japanskim krajevima - od pola metra pa do 3 metra. Japanski javor je pogodan i za uzgoj kao bonsai drvo zbog plitkoga korijenskog sustava i malih zahtjeva za vodom. Za uzgoj u posudama, traži umjereno humusni supstrat, jer će u suprotnom biljka izgubiti neke od svojih prepoznatljivih karakteristika (na primjer crveno lišće). Prednost ovakve sadnje je mobilnost, jer u slučaju prevelike izloženosti suncu, hladu ili vjetru, lako je premjestiti biljku na njoj bolje mjesto u vrtu, kući ili na balkonu. Japanske javore je preporučljivo presađivati svake tri godine (ako je u vrtu), ili svake godine (ako je u loncu ili posudi). U travnju je potrebno japanskom javoru dodati gnojivo s postepenim otpuštanjem hranjivih tvari za kvalitetniji razvoj i rast tipa Osmocote. Ponekad je potrebno orezivanje kako bi se spriječile bolesti biljke, a preporučuje se u razdoblju mirovanja vegetacije, to jest kada otpadne lišće. Kod orezivanja, prvo se uklanjaju polomljene i suhe (mrtve) grančice, a potom one koje su viška i koje pretjerano zgušnjavaju unutrašnjost krošnje. Reže se neposredno iznad para pupova. Nakon što ponovno počnu rasti grane, pojave se dva izbojka, od kojih možemo opet jedan ukloniti. Nakon orezivanja, poželjno je na prerezanu površinu nanijeti voćarski vosak. Kod mladih i cijepljenih biljaka, ponekad se mogu pojaviti divlji izbojci na podlozi što je također potrebno ukloniti. Dok se japanski javor zasađen u vrtu ne treba orezivati sve dokle to nije potrebno, japanski javor koji je posađen u loncu ili posudi zahtjeva stalno orezivanje od svibnja do rujna.

\section{LITERATURA:}

- Dirr, M. A., C. W. Jr Heuser, 1987: Reference Manual of Woody Plant Propagation (From Seed to Tissue Culture), Athens, 239 str.

- Jemrić, T., 2007: Cijepljenje i rezidba voćaka. Naklada Uliks, 180 str.

- MacDonald, B., 1986: Practical Woody Plant Propagation for Nursery Growers. Timper Press, Inc. Oregon, USA, 660 str.

- Međedović, S., D. Ferhatović, 2003: Klonska proizvodnja sadnica drveća i grmlja. Safer Međedović, Sarajevo, 216 str.

- Stilinović, S., 1987: Proizvodnja sadnog materijala šumskog i ukrasnog drveća i žbunja, Univerzitet u Beogradu, Beograd, 455 str.

- van Gelderen, C. J., D. M. van Gelderen, 1999: Maples for Gardens: A Color Encyclopedia. Timber Press, Incorporated, 294 str.

- Young, J. A., C. G. Young, 1992: Seeds of Woody Plants in North America, Portland, 407 str.

- https://www.vrtlarica.com/uzgoj-japanskog-javora/

- http://www.sumins.hr/odjel-rasadnicke-proizvodnje/ 


\section{SUMMIRY}

The article discusses the importance of decorative Japanese maples in landscaping projects and their great variability. The method of production of seed rootstocks and the side-veneer technique of grafting, which is carried out in protected areas in late winter, are explained in detail. All factors to be considered before, during and after grafting are explained. The article clarifies the codes used in the nursery production of grafted plants and is taken from the standards of the European Nurserystock Association (E.N.A.). This professional paper can serve all nurseries as well as individuals who wish to propagate a particular cultivar of Japanese maples.

KEYWORDS: ROOTSTOCK, scion, side-veneer grafting, grafted plants care, E.N.A. standard 